\title{
Tekanan Kepemilikan Saham Pada Audit Delay Di Bursa Efek Indonesia Periode 2016-2019
}

\author{
Baniady Gennody Pronosokodewo ${ }^{\mathrm{a}, *}$ and Rahandhika Ivan Adyaksana ${ }^{\mathrm{b}}$ \\ ${ }^{a}$ Fakultas Bisnis, Universitas PGRI Yogyakarta, baniady@upy.ac.id, Indonesia \\ ${ }^{b}$ Fakultas Bisnis, Universitas PGRI Yogyakarta, rahandhika@upy.ac.id, Indonesia
}

\begin{abstract}
Shareholders want audited financial reports to be published immediately to make precise and accurate economic decisions. Companies were late in publishing audited financial reports can indicate bad news in the company's financial statements. The delay in submitting financial reports can be said to be the length of the company's audit delay, which resulted in the company being sanctioned by the OJK (submission of financial reports should not exceed 31 March). This study aims to analyze whether share ownership consisting of public ownership, institutional ownership and managerial ownership can affect audit delay in companies listed on the IDX during 2016-2019 period. This research uses secondary data from companies that are included in the LQ45 category with purposive sampling method and obtained a sample of 77 companies during 2016-2019. The research hypothesis was tested using SEM method, the statistical tool namely Warp PLS. The results of this study is public ownership has a negative effect on audit delay, institutional ownership has a positive effect on audit delay, and managerial ownership has no effect on audit delay.
\end{abstract}

Keywords: Public Ownership, Institutional Ownership, Managerial Ownership, Audit Delay 


\section{Pendahuluan}

Di zaman berlangsungnya industri 4.0, mulai bermunculan start-up yang dapat memantau secara real time atas pergerakan saham kapan pun dan dimana pun investor atau shareholder berada. Investor juga sudah mulai menyadari bahwa munculnya berbagai macam start-up tersebut dapat membantu untuk meningkatkan income-nya melalui tradding maupun berinvestasi pada saham. Hal ini dapat dibuktikan adanya kenaikkan investor untuk saham secara signifikan dari tahun ke tahun. Kenaikkan tersebut telah dicatat oleh Bursa Efek Indonesia (BEI), yakni dengan meningkatnya nomor identitas investor atau Single Investor Identification (SID) saham menjadi 1,10 juta SID saham di akhir tahun 2019 yang sebelumnya tercatat sebanyak 852.240 SID untuk saham di akhir 2018, dengan total sebanyak $80 \%$ merupakan investor saham pengguna start-up. Dengan adanya start-up atau aplikasi untuk membatu memantau pergerakan saham secara real time, kebutuhan akan informasi keuangan yang cepat/tepat waktu, mudah dipahami, relevan, andal dan dapat dibandingkan menjadi sangat penting bagi shareholder dalam pembuatan keputusan bisnis kedepan seperti menahan saham atau menjual saham maupun melakukan diversifikasi saham dengan membeli saham perusahaan go public lainnya.

Pihak yang paling bertanggung jawab dalam mengungkapkan informasi perusahaan pada laporan keuangan adalah manajemen, karena manajemen yang menjalankan kegiatan bisnis secara langsung. Dewan direksi juga memiliki tanggung jawab dalam menghasilkan laporan keuangan yang berkualitas karena dewan direksi bertugas untuk menyusun laporan keuangan yang dapat diandalkan atau tidak memihak (Mustapha \& Ahmad, 2011). Laporan keuangan perusahaan yang telah diaudit dan menghasilkan opini audit Wajar Tanpa Pengecualian (WTP) akan menarik perhatian investor untuk menginvestasikan dananya di perusahaan tersebut.

Kepercayaan investor dan masyarakat yang akan menanamkan dananya di perusahaan go public harus ditumbuhkan dengan adanya proses audit laporan keuangan perusahaan oleh auditor eksternal atau akuntan publik agar manajemen perusahaan dapat membuktikan bahwa laporan keuangan tahunan perusahaan yang disusun merupakan cerminan kinerja manajemen yang dapat dipertanggungjawabkan atau dapat dikatakan menghasilkan laporan keuangan yang akuntabel.
Rentang waktu yang dibutuhkan auditor eksternal atau akuntan publik untuk melaksanakan proses audit laporan keuangan tahunan menimbulkan adanya audit delay (Ashton et al., 1987). Hasil pemeriksaan akuntan publik pada laporan keuangan diringkas dengan detail dalam sebuah laporan audit yang menyajikan opini laporan keuangan secara keseluruhan. Jika hasil opini auditor eksternal atau akuntan publik terhadap laporan keuangan tahunan perusahaan adalah WTP, maka dapat dikatakan bahwa manajemen telah menyusun dan menyajikan laporan keuangan tahunan perusahaan sesuai dengan prinsip-prinsip akuntansi (Bedard et al., 2010).

Masyarakat, investor, dan manajer yang memiliki saham (shareholder) dalam perusahaan menginginkan laporan keuangan yang diaudit segera dipublikasikan untuk mengetahui pengaruh peningkatan atau penurunan laba-rugi yang dihasilkan maupun dividen yang dibayarkan perusahaan terhadap harga saham perusahaan, adanya peningkatan laba maupun peningkatan pembayaran dividen tersebut merupakan sinyal positif dalam kenaikkan harga saham perusahaan (Khoufi \& Khoufi, 2018). Jika perusahaan tersebut telah mempublikasikan laporan keuangan dan timbul sinyal positif terhadap kenaikkan harga saham, maka shareholder akan cenderung menjual sahamnya. Oleh karena itu, ketepatwaktuan pelaporan keuangan sangat penting dalam pembuatan keputusan bisnis shareholder ke depan terkait menjual saham jika harga meningkat atau menahan saham jika harga saham stabil atau bahkan menurun (Wan-Hussin \& Bamahros, 2013).

Namun, pendapat Ramalingegowda \& Yu (2012) menyatakan bahwa kepemilikan saham oleh pihak institusional lebih mementingkan kehati-hatian dalam mengaudit laporan keuangan. Kehati-hatian dalam mengaudit laporan keuangan tersebut diharapkan dapat menghasilkan laporan keuangan auditan yang tidak merugikan pihak institusional, karena dana investasi dari pihak institusional merupakan dana dari berbagai pihak. Oleh karena itu, pihak institusional berharap laporan keuangan auditan dapat memberikan informasi berkualitas untuk membuat keputusan ekonomi yang akurat, sehingga pihak institusional mendapatkan keuntungan dari menginvestasikan dananya di perusahaan tersebut.

Otoritas Jasa Keuangan (OJK) sebagai badan yang salah satu tugasnya yaitu mengawasi pasar modal menggantikan Bapepam-LK masih menggunakan Keputusan Ketua Bapepam Nomor 
346/BL/Tahun 2011 yang mewajibkan emiten untuk menyampaikan laporan keuangan tahunan perusahaan yang sudah diaudit beserta Laporan Auditor Independen (LAI) oleh Kantor Akuntan Publik (KAP) maksimal 90 hari (31 Maret) setelah tanggal laporan keuangan tahunan (31 Desember). Semakin panjang waktu yang dibutuhkan dalam proses auditing, maka semakin lama laporan keuangan tahunan perusahaan yang sudah diaudit, sehingga laporan keuangan tahunan perusahaan yang sudah diaudit melebihi waktu 90 hari akan dikenai sanksi oleh OJK.

\section{Tinjauan Pustaka}

\section{Teori Keagenan}

Jensen \& Meckling (1976) memberikan penjelasan timbulnya interaksi keagenan dikarenakan adanya ikatan kerja antara prinsipal dan agen, prinsipal membutuhkan agen untuk menjalankan kegiatan bisnis dengan prinsipal sebagai investor, sehingga pihak agen harus akuntabel dalam menyusun pelaporan keuangan perusahaan yang mencerminkan kinerja manajemen selama satu periode. Hubungan keagenan yang muncul karena pihak agen menyetujui dan menandatangani ikatan kerja yang diberikan oleh pihak prinsipal, sehingga mengakibatkan pihak agen mengetahui lebih banyak kondisi internal dan eksternal perusahaan daripada pihak prinsipal atau sering disebut dengan adanya informasi asimetri. Hal ini disebabkan pihak agen yang diberikan wewenang oleh pihak prinsipal untuk mengelola kegiatan bisnis dan mengelola dana yang diinvestasikan oleh prinsipal, sehingga pihak agen mengetahui lebih banyak kondisi internal dan eksternal daripada pihak prinsipal. Berkaitan dengan timbulnya hubungan keagenan, praktek pelaporan keuangan dalam perusahaan go public sangat didasari oleh teori keagenan, manajemen perusahaan yang bertindak sebagai agen mempunyai kewajiban dalam mempertanggung-jawabkan pengelolaan sumber daya terutama keuangan dalam bentuk laporan keuangan sebagai informasi yang bermanfaat bagi shareholders atau pengguna informasi keuangan (prinsipal) seperti investor, pelaku ekonomi, maupun masyarakat. Shareholders membutuhkan laporan keuangan sebagai bentuk pertanggungjawaban manajemen terhadap dana yang ditanamkan pada perusahaan tersebut.
Menurut Panda \& Leepsa (2017), untuk mengurangi informasi asimetri, manajemen perusahaan sebagai pihak agen berkewajiban memberikan pertanggungjawaban kinerja manajemen dengan mengungkapkan, menyajikan, dan melaporkan seluruh transaksi dan aktivitas selama satu periode secara faktual dan andal yang menjadi tanggung jawab manajemen kepada pihak prinsipal yaitu shareholder yang mempunyai hak untuk mengetahui laporan keuangan tiap periode. Oleh karena itu muncul adanya biaya keagenan untuk mengurangi adanya informasi asimetri antara shareholders dengan pihak manajemen perusahaan. Menurut Mustapha \& Ahmad (2011), biaya keagenan dapat berkurang dengan adanya kepemilikan manajerial yang besar. Besarnya kepemilikan manajerial membuat manajemen perusahaan lebih berhati-hati dalam membuat keputusan, sehingga tidak merugikan diri sendiri. Hal ini dapat meminimalisir adanya informasi asimetri antara prinsipal dengan agen. Namun, dengan adanya kepemilikan manajemen yang besar ditakutkan timbulnya kebocoran informasi terkait saham sebelum laporan keuangan dipublikasikan. Oleh karena itu, untuk menjaga manajemen tetap pada jalur visi perusahaan banyak negara yang menetapkan sistem two-tier untuk menghalangi manajemen berbuat kecurangan lebih besar. Dengan begitu informasi asimetri antara pihak prinsipal dengan pihak agen dapat diperkecil dan sekaligus memperkecil kecenderungan pihak agen melakukan kecurangan atau fraud.

Menurut Zogning (2017), pertanggungjawaban yang dilakukan oleh pihak agen berupa penyusunan pelaporan keuangan diharapkan dapat meningkatkan kepercayaan pihak prinsipal dengan cara mengaudit laporan keuangan perusahaan secara keseluruhan oleh auditor eksternal atau akuntan publik yang akhirnya menghasilkan laporan audit. Laporan audit merupakan gambaran kesimpulan yang ditarik terkait proses awal hingga akhir dalam melakukan pemeriksaan laporan keuangan perusahaan. Suryanto (2016) menjelaskan bahwa laporan audit merupakan alat untuk mengomunikasikan secara formal kepada pihak prinsipal tentang apa yang telah dilakukan akuntan publik dalam mengaudit laporan keuangan yang merupakan laporan pertanggungjawaban dari pihak agen, sehingga pihak agen harus menyusun laporan keuangan yang berkualitas atau laporan keuangan yang tidak mengandung kecurangan atau fraud. 
Penelitian ini menggunakan teori keagenan yang diaplikasikan pada kerangka penelitian ini yaitu shareholder sebagai pihak prinsipal yang mendapatkan informasi yang minim terkait kinerja perusahaan dibandingkan dengan manajemen perusahaan sebagai pihak agen, karena manajemen perusahaan merupakan pihak yang menjalankan kegiatan bisnis perusahaan, sedangkan shareholder hanya mengamati tindakan manajemen perusahaan. Shareholder menginginkan kegiatan yang dilakukan manajemen perusahaan tidak menimbulkan kerugian pada dana yang diinvestasikannya. Oleh karena itu, manajemen wajib mempertanggungjawabkan kegiatan bisnis yang dijalankannya dengan cara menyusun laporan keuangan perusahaan. Laporan keuangan perusahaan wajib diaudit untuk memberikan kepercayaan terhadap shareholders bahwasanya informasi yang mereka susun terbukti disusun secara andal dan tidak mengandung kecurangan, sehingga dapat dipublikasikan secara tepat waktu. Laporan keuangan perusahaan yang dipublikasikan secara tepat waktu dapat meningkatkan kualitas informasi pada laporan keuangan perusahaan tersebut, sehingga shareholder dapat mengambil keputusan dari laporan keuangan yang dipublikasikan secara cepat, tepat dan akurat.

\section{Audit Delay}

Akuntan publik wajib menyusun laporan audit setelah selesai mengaudit laporan keuangan suatu perusahaan. Menurut De George et al., (2016) laporan audit harus memuat opini auditor yang merupakan penilaian secara keseluruhan pada laporan keuangan sesuai dengan asersi. Tanggung jawab akuntan publik dalam melaksanakan audit laporan keuangan sangatlah besar. Menurut Abbott et al., (2012) akuntan publik bertanggung jawab dalam memberikan penilaian laporan keuangan tahunan perusahaan berupa opini audit karena mencakup pengambilan keputusan para pengguna laporan keuangan. Namun, akuntan publik juga memiliki hak untuk tidak memberikan pendapat secara keseluruhan dengan memberikan alasan dan temuan sesuai dengan asersi yang dilakukan akuntan publik. Diterbitkannya laporan audit merupakan berakhirnya proses audit pada laporan keuanga tahunan auditee. Laporan audit disusun setelah akuntan publik menyelesaikan pekerjaan lapangan (audit field works).
Laporan keuangan yang sudah diaudit membutuhkan waktu maksimal 90 hari untuk kemudian digunakan oleh para stakeholder atau pengguna laporan keuangan untuk membuat keputusan terkait forecasting and budgeting dalam kegiatan bisnis mendatang dengan asumsi bahwa informasi laporan keuangan tersebut wajar agar dapat diandalkan. Menurut Ashton et al., (1987) lamanya waktu pelaksanaan proses audit laporan keuangan tahunan perusahaan diukur berdasarkan jumlah hari disebut dengan audit delay. Laporan Auditor Independen (LAI) dibutuhkan stakeholder sebagai bukti bahwa laporan keuangan tahunan sudah diaudit dan memperoleh opini yang optial yaitu WTP terhitung sejak tanggal tutup buku periode perusahaan yaitu 31 Desember sampai dengan tanggal ditandatanganinya Laporan Auditor Independen (LAI).

Carslaw \& Kaplan (1991) menjelaskkan bahwa, ketepatanwaktuan menyampaikan pelaporan keuangan tahunan perusahaan dapat mempengaruhi kualitas informasi laporan keuangan tahunan perusahaan. Lamanya waktu yang dibutuhkan untuk melaksanakan audit laporan keuangan mengindikasikan audit delay perusahaan tersebut semakin panjang. Proses audit memerlukan banyak waktu, semakin panjang waktu pelaksanaan audit pada laporan keuangan akan menyebabkan audit delay yang lebih lama dan dapat mempengaruhi keterlambatan penyampaian laporan keuangan yang telah diaudit oleh akuntan publik kepada OJK. Oleh karena itu, terlambatnya penyampaian laporan keuangan tahunan perusahaan yang sudah diaudit dapat mempengaruhi kualitas informasi. Hal ini menimbulkan lamanya audit delay yang menunjukan bahwa informasi yang ada pada laporan keuangan tidak up to date, sehingga stakeholder mengindikasikan adanya kualitas informasi dari laporan keuangan yang telah diaudit tersebut buruk (Ishak et al., 2010).

\section{Kepemilikan Publik}

Modal merupakan faktor terpenting dalam mendirikan suatu perusahaan. Perusahaan dapat mendapatkan modal secara mudah dengan cara listed pada bursa efek atau sudah melaksanakan Initial Public Offering (IPO) pada Bursa Efek Indonesia (BEI). Perusahaan atau emiten yang sudah listed di BEI akan bersifat terbuka atau go public. Perusahaan yang sudah go public dapat dengan mudah menjual sahamnya kepada para investor 
termasuk masyarakat yang ingin menginvestasikan dananya. Semakin banyak modal yang dibutuhkan perusahaan, maka semakin banyak pula lembar saham yang dijual di pasar modal yang menyebabkan banyaknya lembar saham beredar. Kepemilikan publik adalah banyaknya lembar saham perusahaan yang dimiliki oleh masyarakat. Proporsi saham yang dimiliki oleh masyarakat ditentukan oleh persentase jumlah saham yang dimiliki oleh masyarakat atau publik yang diungkapkan pada laporan keuangan tahunan yaitu pada Catatan atas Laporan Keuangan (Givoly et al., 2010).

Kepemilikan saham oleh pihak publik menyebabkan adanya tekanan yang didapatkan oleh perusahaan karena semua kegiatan ekonomi perusahaan dan isu-isu terkait perusahaan akan selalu dipantau oleh publik, sehingga setiap keputusan yang dibuat manajemen akan memperoleh tanggapan dari masyarakat atau publik (Fakhfakh, 2015). Pihak publik juga memiliki hak untuk menekan manajemen perusahaan agar secepatnya mempublikasikan laporan keuangan yang telah diaudit. Menurut Payne \& Jensen (2002) perusahaan yang terlambat menyampaikan laporan keuangan auditan dapat mempengaruhi keputusan investasi yang akan datang, sehingga para pemilik investasi akan berpikir adanya sinyal negatif pada laporan keuangan. Besarnya persentase saham yang dimiliki oleh masyarakat atau publik mengindikasikan adanya tekanan dari masyarakat yang lebih besar untuk segera menyampaikan laporan keuangan auditan kepada OJK. Perusahaan dengan persentase kepemilikan publik yang besar, memiliki kecenderungan untuk lebih tepat waktu dalam menyampaikan laporan keuangan tahunan perusahaan yang sudah diaudit kepada OJK untuk menjaga kepercayaan masyarakat yang menginvestasikan dananya pada perusahaan.

\section{Kepemilikan Institusional}

Proses pelaksanaan audit atas laporan keuangan secara independen meyakinkan stakeholder bahwa laporan keuangan tahunan yang disusun dan disajikan oleh manajemen tersebut andal dan akuntabel, sehingga keputusan bisnis kedepan yang dibuat oleh shareholder akurat dan tepat sasaran. (Fakhfakh, 2015). Besarnya persentase kepemilikan saham menunjukkan adanya kekuasaan dalam memegang kendali suatu perusahaan yang berimplikasi pada penentuan prosedur dan kebijakan dalam monitoring pembuatan keputusan manajemen. Shareholder yang memiliki pengaruh dalam RUPS salah satunya adalah institusional (institutional ownership). Kepemilikan saham oleh perusahaan yang bergerak di bidang keuangan atau biasa disebut pihak institusional menyebabkan adanya tekanan yang didapatkan oleh perusahaan karena seluruh kegiatan bisnis perusahaan akan selalu ditinjau dan dikontrol oleh pihak institusional, sehingga setiap keputusan yang dibuat oleh manajemen akan mendapatkan tangapan dari institusional. Kepemilikan institusional adalah banyaknya lembar saham perusahaan yang dimiliki oleh pihak institusional. Proporsi saham yang dimiliki oleh pihak institusional ditentukan oleh persentase kepemilikan saham oleh pihak institusional yang diungkapkan pada laporan keuangan tahunan atau dapat dilihat pada Annual Report (Cornett et al., 2007).

Intitutional ownership juga memiliki hak untuk menekan manajemen perusahaan untuk menyusun laporan keuangan yang berkualitas. Intitutional ownership tidak ingin dana yang diinvestasikan pada saham perusahaan tersebut rugi (loss), karena dana yang diinvestasikan tersebut merupakan dana dari berbagai macam pihak (Bird \& Karolyi, 2016). Cornett et al., (2007) menjelaskan bahwa besarnya kepemilikan institusional (intitutional ownership) pada perusahaan, mengakibatkan adanya tekanan perusahaan untuk mendapatkan profit yang semakin meningkat. Bertambahnya profit perusahaan mengindikasikan adanya kinerja atau performance yang baik. Hal ini dapat menghasilkan informasi laporan keuangan tahunan perusahaan yang berkualitas, sehingga akuntan publik atau auditor eksternal cenderung lebih cepat dalam mengaudit laporan keuangan. Namun, intitutional ownership lebih menekankan untuk melakukan proses audit secara berhati-hati, karena dana yang diinvestasikan oleh intitutional ownership merupakan dana dari berbagai pihak. Jadi kecenderungan manajemen menginginkan terselesaikannya pelakasanaan audit dengan berhati-hati sangatlah tinggi agar intitutional ownership dapat mengembalikan dana dari berbagai pihak sekaligus mendapatkan keuntungan dari dividen dan gain dari penjualan saham (Ramalingegowda \& Yu, 2012).

\section{Kepemilikan Manajerial}

Kepemilikan manajerial merupakan persentase jumlah lembar saham suatu perusahaan go public 
yang dimiliki pihak manajemen perusahaan itu sendiri (Coles et al., 2012). Namun, manajemen yang memiliki saham di perusahaan dia bekerja tidak boleh menyusun pelaporan keuangan dengan informasi yang menguntungkan pihak tertentu termasuk pihak manajemen itu sendiri atau merugikan pihak lain yang mempunyai kepentingan berlawanan. Laporan keuangan yang sudah diaudit membutuhkan waktu maksimal 90 hari untuk kemudian digunakan oleh shareholder untuk membuat keputusan ekonomi ke depan dengan asumsi bahwa informasi laporan keuangan perusahaan wajar agar dapat diandalkan. Menurut Millet-Reyes \& Zhao (2010) untuk mengurangi kecurangan manajemen dalam memiliki saham perusahaan tersebut, Good Corporate Governance mengatur sistem pengawasan perusahaan yaitu onetier dan two-tier. Peran dewan komisaris dan dewan direksi pada one-tier system dijadikan dalam satu struktur yang disebut Board Of Director (BOD), sehingga tidak ada pemisahan tugas antara pelaksana dan pengawas. Namun, peran dewan komisaris dan dewan direksi pada two-tier system dipisah, sehingga ada pemisahan tugas antara pelaksana dan pengawas yang dapat meminimalisir kecurangan.

Saham yang dimiliki oleh manajemen mengakibatkan manajemen perusahaan meningkatkan performance agar dapat menyajikan informasi pada laporan keuangan secara berkualitas, sehingga dapat segera mempublikasikan laporan keuangan yang telah diaudit. Besarnya persentase saham yang dimiliki pihak manajemen, mengindikasikan tingginya tekanan perusahaan untuk segera mempublikasikan laporan keuangan. Menurut Lafond \& Roychowdhury (2008), kepemilikan perusahaan oleh manajer akan mempengaruhi akuntabilitas manajemen, sehingga tingkat manipulasi data pada laporan keuangan akan berkurang dan dapat mengoptimalkan proses audit. Besarnya persentase saham yang dimiliki pihak manajemen cenderung untuk segera menyampaikan laporan keuanganyang telah diaudit kepada OJK untuk menjaga kepercayaan para investor publik. Hal ini menyebabkan manajemen menginginkan terselesaikannya pelakasanaan audit dengan cepat sangatlah tinggi agar dapat segera menyampaikan laporan keuangan kepada OJK.

\section{Pengaruh Kepemilikan Publik terhadap Audit Delay}

Kepercayaan investor dan masyarakat yang akan menanamkan dananya di perusahaan go public harus ditumbuhkan dengan adanya proses audit laporan keuangan perusahaan oleh auditor eksternal atau akuntan publik agar laporan keuangan tahunan perusahaan yang disusun dan disajikan oleh manajemen adalah cerminan kinerja manajemen yang dapat dipertanggungjawabkan atau dapat dikatakan menghasilkan laporan keuangan yang akuntabel. Waktu yang dibutuhkan auditor dalam mengaudit laporan keuangan tahunan menimbulkan adanya audit delay atau lamanya akuntan publik untuk mengaudit laporan keuangan perusahaan sampai dengan menyusun Laporan Audit (Ashton et al., 1987). Laporan keuangan yang diaudit membutuhkan waktu maksimal 90 hari untuk kemudian digunakan oleh shareholder untuk membuat keputusan ekonomi kedepan dengan asumsi bahwa informasi laporan keuangan perusahaan wajar agar dapat diandalkan.

Publik yang memiliki saham dalam perusahaan menginginkan laporan keuangan perusahaan yang diaudit segera dipublikasikan untuk mengetahui pengaruh peningkatan atau penurunan laba-rugi yang dihasilkan maupun dividen yang dibayarkan perusahaan terhadap harga saham perusahaan, adanya peningkatan laba maupun peningkatan pembayaran dividen tersebut merupakan sinyal positif dalam kenaikkan harga saham perusahaan (Khoufi \& Khoufi, 2018). Kepemilikan saham oleh pihak publik menyebabkan adanya tekanan yang didapatkan oleh perusahaan karena semua kegiatan ekonomi perusahaan dan isu-isu terkait perusahaan akan selalu dipantau oleh publik, sehingga setiap keputusan yang dibuat manajemen akan memperoleh tanggapan dari masyarakat atau publik (Fakhfakh, 2015). Perusahaan dengan persentase kepemilikan publik yang besar, cenderung lebih tepat waktu dalam menyampaikan laporan keuangan yang sudah diaudit untuk menjaga kepercayaan masyarakat yang menginvestasikan dananya pada perusahaan. Oleh karena itu, besarnya persentase lembar saham yang dimiliki masyarakat atau publik menyebabkan manajemen cenderung mengingin-kan laporan keuangan yang diaudit segera disampaikan 
kepada OJK untuk menjaga keper-cayaan para investor publik.

$\mathrm{H}_{1}$ : Kepemilikan publik berpengaruh negatif terhadap audit delay

\section{Pengaruh Kepemilikan Institusional terhadap Audit Delay}

Menurut Ashton et al., (1987) pihak agen harus memiliki akuntabilitas sebagai kewajiban pemegang amanah. Hal ini menyebabkan manajemen perusahaan sebagai pihak agen berkewajiban memberikan pertanggungjawaban kinerja manajemen dengan mengungkapkan, menyajikan, dan melaporkan seluruh transakasi, aktivitas dan kegiatan bisnis yang menjadi tanggungjawab manajemen atau pihak agen kepada pihak prinsipal yaitu shareholder yang memiliki hak untuk meminta pertanggungjawaban kinerja manajemen berupa laporan keuangan tahunan. Carslaw \& Kaplan (1991) menjelaskkan bahwa, ketepatan waktu dalam menyusun pelaporan keuangan perusahaan dapat mempengaruhi kualitas laporan keuangan tahunan perusahaan. Semakin lama waktu yang dibutuhkan untuk mengaudit laporan keuangan, maka semakin panjang audit delay perusahaan tersebut. Proses audit memerlukan banyak waktu, waktu yang semakin panjang mengakibatkan lamanya audit delay yang nantinya berpengaruh pada keterlambatan penyampaian laporan keuangan kepada OJK.

Besarnya persentase kepemilikan saham menunjukkan adanya kekuasaan dalam memegang kendali suatu perusahaan yang berimplikasi pada penentuan prosedur dan kebijakan dalam monitoring pembuatan keputusan manajemen. Kepemilikan saham oleh pihak institusional (intitutional ownership) menyebabkan adanya tekanan pada manajemen perusahaan untuk menyusun laporan keuangan yang berkualitas. Intitutional ownership tidak ingin dana yang diinvestasikan pada saham perusahaan tersebut rugi (loss), karena dana yang diinvestasikan tersebut merupakan dana dari berbagai macam pihak (Bird \& Karolyi, 2016). Intitutional ownership lebih menekankan untuk melakukan proses audit secara berhati-hati, karena dana yang diinvestasikan oleh intitutional ownership merupakan dana dari berbagai pihak (Ramalingegowda \& Yu, 2012). Kecenderungan manajemen menginginkan terselesaikannya pelakasanaan audit dengan berhati-hati sangatlah tinggi agar intitutional ownership dapat mengembalikan dana dari berbagai pihak sekaligus mendapatkan keuntungan dari dividen dan gain dari penjualan saham. Oleh karena itu, banyaknya jumlah lembar saham yang dimiliki oleh perusahaan yang bergerak di bidang keuangan atau pihak institusional mengindikasikan waktu yang digunakan untuk melaksanakan proses audit bertambah lama, sehingga waktu untuk menyampaikan laporan keuangan tahunan perusahaan yang telah diaudit bertambah lama.

$\mathrm{H}_{2}$ : Kepemilikan institusional berpengaruh positif terhadap audit delay

Pengaruh Kepemilikan Manajerial terhadap Audit Delay

Menurut Abbott et al., (2012) akuntan publik bertanggung jawab dalam memberikan opini audit terhadap laporan keuangan auditee karena mencakup pengambilan keputusan para pengguna laporan keuangan. Laporan audit disusun berdasarkan proses audit laporan keuangan suatu perusahaan. Proses audit memerlukan banyak waktu, semakin panjang waktu pelaksanaan audit pada laporan keuangan akan menyebabkan audit delay yang lebih lama dan dapat mempengaruhi ketidaktepatan penyampaian laporan keuangan yang telah diaudit kepada OJK. Oleh karena itu, terlambatnya penyampaian laporan keuangan tahunan yang sudah diaudit dapat menurunkan kualitas informasi laporan keuangan tahunan perusahaan karena menimbulkan lamanya audit delay yang mengindikasikan adanya informasi laporan keuangan yang tidak up to date, sehingga stakeholder mengindikasikan adanya kualitas informasi dari laporan keuangan yang telah diaudit tersebut buruk (Ishak et al., 2010).

Saham yang dimiliki oleh manajemen mengakibatkan manajemen perusahaan meningkatkan performance agar dapat menyajikan informasi pada laporan keuangan secara berkualitas, sehingga dapat segera mempublikasikan laporan keuangan yang telah diaudit. Semakin besar persentase saham yang dimiliki pihak manajemen, maka semakin besar tekanan perusahaan dalam mempublikasikan laporan keuangan tepat waktu. Lafond \& Roychowdhury (2008) menyatakan bahwa kepemilikan perusahaan oleh manajer akan mempengaruhi akuntabilitas manajemen, sehingga tingkat manipulasi data pada laporan keuangan akan berkurang dan dapat mengoptimalkan proses audit. Besarnya persentase jumlah lembar saham yang 
dimiliki oleh manajemen, cenderung menginginkan laporan keuangan yang diaudit segera disampaikan kepada OJK untuk menjaga kepercayaan para shareholder.

$\mathrm{H}_{3}$ : Kepemilikan manajerial berpengaruh negatif terhadap audit delay

\section{Metode Penelitian}

Penelitian ini merupakan penelitian dengan metode kuantitatif yang menggunakan data sekunder. Data sekunder dalam penelitian menggunakan informasi dari laporan keuangan tahunan yang sudah diaudit dan diperoleh dari website Bursa Efek Indonesia serta listed pada kategori LQ45 selama tahun 2016-2019. Penelitian ini menggunakan metode purposive sampling dengan ketentuan pengambilan sampel sebagai berikut:

1. Perusahaan-perusahaan yang terdaftar di Bursa Efek Indonesia dan masuk dalam kategori perusahaan LQ45 selama periode 2016 sampai dengan 2019 berturut-turut.

2. Perusahaan-perusahaan tersebut tidak menggunakan mata uang selain Rupiah pada pencatatan pelaporan keuangan tahun 2016 sampai dengan 2019.

3. Perusahaan-perusahaan tersebut tidak mengalami kerugianberturut-turut dalam laporan laba-rugi selama periode tahun 2016 sampai dengan 2019.

4. Perusahaan-perusahaan tersebut memiliki data yang diperlukan seperti tanggal pelaporan auditor dan informasi kepemilikan saham.

\section{Definisi Operasional Variabel}

\section{Audit Delay}

Carslaw \& Kaplan (1991) menjelaskkan bahwa, ketepatwaktuan dalam menyusun pelaporan keuangan tahunan perusahaan dapat mempengaruhi kualitas laporan keuangan tahunan perusahaan. Semakin lama waktu yang dibutuhkan untuk mengaudit laporan keuangan, maka semakin panjang audit delay perusahaan tersebut. Proses audit memerlukan banyak waktu, semakin panjang waktu pelaksanaan audit pada laporan keuangan akan menyebabkan audit delay yang lebih lama dan dapat mempengaruhi ketidaktepatan penyampaian laporan keuangan yang telah diaudit kepada OJK. Menurut Ashton et al., (1987) lamanya waktu pelaksanaan proses audit pada laporan keuangan tahunan diukur berdasarkan lamanya jumlah hari disebut dengan audit delay. Laporan Auditor
Independen (LAI) dibutuhkan stakeholder sebagai bukti bahwa laporan keuangan tahunan sudah diaudit dan memperoleh opini yang optimal yaitu WTP terhitung sejak tanggal tutup buku periode perusahaan yaitu 31 Desember sampai dengan tanggal ditandatanganinya Laporan Auditor Independen (LAI).

OJK sebagai badan yang salah satu tugasnya yaitu mengawasi pasar modal menggantikan BapepamLK masih menggunakan Keputusan Ketua Bapepam Nomor 346/BL/Tahun 2011 yang mewajibkan emiten secepatnya menyampaikan laporan keuangan tahunan perusahaan yang telah diaudit beserta Laporan Auditor Independen (LAI) oleh Kantor Akuntan Publik (KAP) maksimal 90 hari (31 Maret) setelah tanggal laporan keuangan tahunan (31 Desember) kepada OJK. Semakin panjang waktu yang dibutuhkan dalam proses auditing, maka semakin lama waktu emiten dalam menyajikan laporan keuangan tahunan perusahaan yang sudah diaudit kepada OJK dan masyarakat publik, sehingga emiten yang terlambat (melebihi waktu 90 hari) menyajikan laporan keuangan tahunan perusahaan yang telah diaudit akan dikenai sanksi oleh OJK. Variabel audit delay diukur dengan melihat tanggal laporan audit yang sudah ditandatangani oleh auditor.

\section{Kepemilikan Publik}

Modal merupakan faktor terpenting dalam mendirikan suatu perusahaan. Perusahaan dapat mendapatkan modal secara mudah dengan cara mendaftarkan nama perusahaan atau emiten pada bursa efek atau telah melaksanakan Initial Public Offering (IPO) pada Bursa Efek Indonesia (BEI), sehingga perusahaan atau emiten tersebut akan bersifat terbuka atau go public. Perusahaan yang sudah go public dapat dengan mudah menjual sahamnya kepada para investor termasuk masyaraat yang ingin menginvestasikan dananya. Semakin banyak modal yang dibutuhkan perusahaan, maka semakin banyak pula lembar saham yang akan ditawarkan untuk dijual di pasar modal yang menyebabkan banyanya lembar saham beredar. Saham yang ditawarkan untuk dijual di pasar modal juga dapat dibeli oleh masyarakat atau publik. Pihak publik mempunyai hak untuk menekan manajemen perusahaan agar secepatnya mempublikasikan laporan keuangan yang telah diaudit.

Kepemilikan saham oleh pihak publik menyebabkan adanya tekanan yang didapatkan oleh 
perusahaan karena semua kegiatan ekonomi perusahaan dan isu-isu terkait perusahaan akan selalu dipantau oleh publik, sehingga setiap keputusan yang dibuat manajemen akan memperoleh tanggapan dari masyarakat atau publik (Fakhfakh, 2015). Kepemilikan publik adalah persentase banyaknya lembar saham perusahaan yang telah dimiliki oleh masyarakat. Proporsi saham yang dimiliki oleh masyarakat diukur dengan besarnya persentase kepemilikan saham oleh masyarakat atau publik yang diungkapkan pada laporan keuangan tahunan yaitu pada Catatan atas Laporan Keuangan (Givoly et al., 2010).

\section{Kepemilikan Institusional}

Besarnya persentase kepemilikan saham menunjukkan adanya kekuasaan dalam memegang kendali suatu perusahaan yang berimplikasi penentuan pada prosedur dan kebijakan dalam monitoring pembuatan keputusan manajemen. Kepemilikan saham oleh perusahaan yang bergerak di bidang keuangan atau biasa disebut pihak institusional menyebabkan adanya tekanan yang didapatkan oleh perusahaan karena seluruh kegiatan bisnis perusahaan akan selalu ditinjau dan dikontrol oleh pihak institusional, sehingga setiap keputusan yang dibuat oleh manajemen akan mendapatkan tangapan dari institusional.

Intitutional ownership juga memiliki hak untuk menekan manajemen perusahaan untuk menyusun laporan keuangan yang berkualitas. Intitutional ownership tidak ingin dana yang diinvestasikan pada saham perusahaan tersebut rugi (loss), karena dana yang diinvestasikan tersebut merupakan dana dari berbagai macam pihak (Bird \& Karolyi, 2016). Kepemilikan institusional adalah banyaknya persentase lembar saham perusahaan yang telah dimiliki oleh pihak institusional. Proporsi saham yang telah dimiliki oleh pihak institusional diukur dengan besarnya persentase kepemilikan saham oleh pihak institusional yang diungkapkan pada laporan keuangan tahunan atau Annual Report (Cornett et al., 2007).

\section{Kepemilikan Manajerial}

Saham yang dimiliki oleh manajemen mengakibatkan manajemen perusahaan meningkatkan performance agar dapat menyajikan informasi pada laporan keuangan secara berkualitas, sehingga dapat segera mempublikasikan laporan keuangan yang telah diaudit. Besarnya persentase saham yang dimiliki pihak manajemen mengindikasikan tingginya tekanan perusahaan untuk segera mempublikasikan laporan keuangan. Manajemen yang memiliki saham di perusahaan dia bekerja tidak boleh menyusun pelaporan keuangan dengan informasi yang menguntungkan pihak tertentu termasuk pihak manajemen itu sendiri atau merugikan pihak lain yang mempunyai kepentingan berlawanan (Mustapha \& Ahmad, 2011).

Lafond \& Roychowdhury (2008) menyatakan bahwa kepemilikan perusahaan oleh manajer akan mempengaruhi akuntabilitas manajemen, sehingga tingkat manipulasi data pada laporan keuangan akan berkurang dan dapat mengoptimalkan proses audit. Besarnya persentase jumlah lembar saham yang telah dimiliki oleh manajemen menyebabkan perusahaan memiliki kecenderungan menginginkan laporan keuangan yang diaudit segera disampaikan kepada OJK untuk menjaga kepercayaan para investor publik. Kepemilikan manajerial merupakan persentase jumlah lembar saham suatu perusahaan go public yang dimiliki pihak manajemen perusahaan itu sendiri (Coles et al., 2012).

\section{Hasil dan Pembahasan}

Tabel 1 menunjukkan jumlah data berdasarkan kriteria dalam menentukan sampel penelitian. Tabel 1 menunjukkan adanya 6 perusahaan yang tidak sesuai kriteria dari periode 2016 sampai dengan 2019, dikarenakan menggunakan mata uang asing dan mengalami kerugian, dengan demikian jumlah sampel penelitian sebanyak 21 perusahaan dalam setahun dan 84 perusahaan selama 4 tahun. Setelah dilakukan goodness of fit test terdapat 7 data outliers yang harus dibuang untuk mendapatkan sampel yang fit atau layak untuk dijadikan sampel penelitian, sehingga dapat dilanjutkan ke tahap pengujian hipotesis.

Tabel 1

Sampel Penelitian

\begin{tabular}{ll}
\hline \multicolumn{1}{c}{ Keterangan } & Jumlah \\
\hline Perusahaan terdaftar di Bursa Efek Indonesia dan & 27 \\
tercatat dalam kategori perusahaan LQ45 selama & \\
periode 2016 sampai dengan 2019 berturut-turut & \\
Perusahaan yang menggunakan mata uang asing & $(4)$ \\
Perusahaan yang mengalami kerugian & $(2)$ \\
Perusahaan yang sesuai dengan kriteria sampel & 21 \\
Data sampel selama 4 tahun & 84 \\
Data yang menyimpang & $(7)$ \\
Jumlah data sampel yang digunakan & 77
\end{tabular}




\section{Analisis Statistik Deskriptif}

Data sampel penelitian wajib dianalisis dengan menggunakan statistik deskriptif untuk mengetahui karakteristik sampel terkait nilai minimum, nilai maksimum, nilai rata-rata (mean), dan standar deviasi dari data penelitian.

Tabel 2

Statistik Deskriptif

\begin{tabular}{lllllr}
\hline Varia-bel & N & Min & Maks & Mean & $\begin{array}{r}\text { Std. } \\
\text { Dev }\end{array}$ \\
\hline AUD & 77 & 29 & 99 & 66,143 & 15,80 \\
PUB & 77 & 0,075 & 0,825 & 0,3659 & 0,152 \\
INS & 77 & 0 & 0,7 & 0,1404 & 0,231 \\
MNG & 77 & 0 & 0,009 & 0,0020 & 0,003 \\
\hline
\end{tabular}

Berdasarkan Tabel 2 nilai rata-rata variabel audit delay sebesar 66,143 yang menunjukkan rata-rata audit delay pada perusahaan yang terdaftar di LQ45 adalah 66 hari, artinya rata-rata perusahan yang terdaftar di LQ45 memiliki audit delay 66 hari atau bisa dikatakan dibawah 90 hari. Variabel kepemilikan publik memiliki rata-rata 0,3659 atau dalam pembahasan ini memiliki rata rata $36,59 \%$, artinya rata-rata kepemilikan publik seluruh perusahaan yang terdaftar di LQ45 sebesar 36,59\%. Variabel kepemilikan institusional memiliki rata rata 0,6929 atau dalam pembahasan ini memiliki nilai rata rata sebesar $69,29 \%$ yang menunjukkan ratarata kepemilikan institusional seluruh perusahaan yang terdaftar di LQ45 sebesar 69,29\%. Sedangkan variabel kepemilikan manajerial pada penelitian ini memiliki nilai rata-rata sebesar 0,0020 atau dalam pembahasan ini memiliki rata rata $0,2 \%$ yang artinya rata-rata kepemilikan manajerial seluruh perusahaan yang terdaftar di LQ45 sebesar 0,2\%.

\section{Analisis Inner Model}

Menurut Hair et al., (2019) metode pengujian statistik menggunakan Structural Equation Modelling (SEM) dengan alat uji statistic yaitu WarpPLS terdiri dari tiga tahapan yaitu outer model, inner model, dan pengujian hipotesis. Penelitian ini tidak menggunakan outer model karena penelitian ini menggunakan data sekunder yang tidak memerlukan indikator untuk mengukur variabel eksogen. Model struktural inner model pada penelitian ini dapat dikatakan fit atau layak untuk dijadikan sampel penelitian dengan melihat nilai pada Goodness of Fit Test.

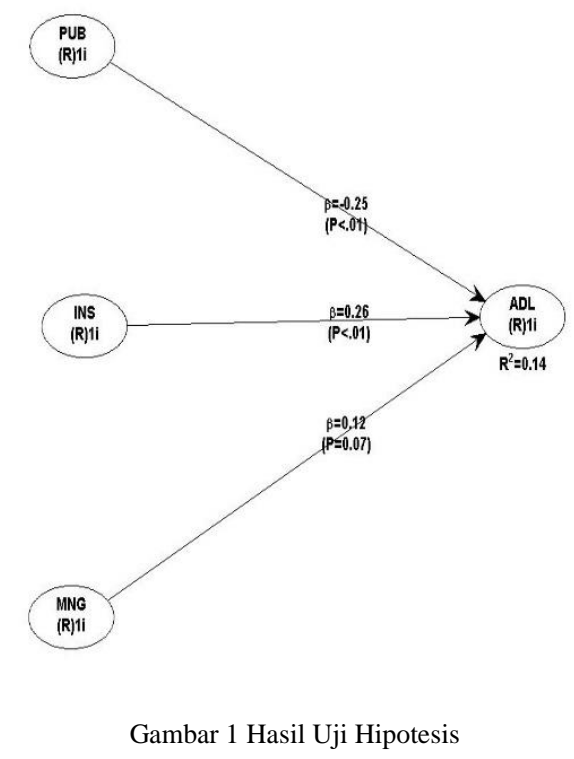

Gambar 1 menunjukkan nilai $\mathrm{R}^{2}$ variabel endogen pada penelitian ini sebesar 0,14 atau $14 \%$, dapat dikatakan model penelitian yang meliputi variabel kepemilikan publik, kepemilikan institusional, dan kepemilikan manajerial mampu menjelaskan variabel audit delay sebesar $14 \%$, sisanya sebesar $86 \%$ adalah variabel yang tidak diuji pada penelitian ini. Penelitian dapat dilanjutkan pada tahap pengujian hipotesis apabila dikatakan fit atau layak untuk dijadikan sampel penelitian, jika nilai $p$-value dari ARS dan APC tidak boleh melebihi dari 5\%, serta nilai AVIF juga tidak boleh melebihi nilai 5.

Tabel 3

Goodness of Fit Test

\begin{tabular}{llll}
\hline \multicolumn{1}{c}{ Hasil } & p-value & \multicolumn{1}{c}{ Kriteria } & Keterangan \\
\hline APC $=$ & 0,004 & $<0,05$ & Diterima \\
$\mathbf{0 , 2 0 9}$ & & & \\
ARS $=$ & 0,025 & $<0,05$ & Diterima \\
$\mathbf{0 , 1 4 0}$ & & & \\
$\mathbf{A V I F}=$ & & $<5$, & Diterima \\
$\mathbf{1 , 5 5 2}$ & & ideally $<3$ & \\
\hline
\end{tabular}

Uji Pengaruh Kepemilikan Publik terhadap Audit Delay

Hasil uji hipotesis penelitian ini yang ditunjukkan pada Gambar 1 membuktikan bahwa hipotesis pertama $\left(\mathrm{H}_{1}\right)$ yaitu variabel kepemilikan publik berpengaruh negatif terhadap audit delay didukung. Didukungnya hipotesis pertama $\left(\mathrm{H}_{1}\right)$ dapat ditunjukkan dengan nilai $p$-value sebesar $<0.01$ yang kurang dari 0.05 dan nilai beta negatif $(-0,25)$. 
Hipotesis pertama $\left(\mathrm{H}_{1}\right)$ pada penelitian ini didukung, sehingga mendukung penelitian yang dilakukan oleh Juanita \& Satwiko (2012), Napisah \& Ramadhani (2020), Fakhfakh, (2015), dan Metta \& Effriyanti (2020). Kepercayaan investor dan masyarakat yang akan menanamkan dananya di perusahaan go public harus ditumbuhkan dengan disampaikannya laporan keuangan tahunan perusahaan yang telah diaudit oleh auditor eksternal atau akuntan publik, sehingga laporan keuangan tahunan yang disusun dan disajikan oleh manajemen perusahaan merupakan laporan keuangan tahunan perusahaan yang akuntabel. Proses audit tersebut yang menimbulkan adanya rentang waktu yang dibutuhkan akuntan publik atau auditor eksternal (audit delay) menyusun dan menyajikan laporan keuangan tahunan perusahaan yang telah diaudit sampai dengan terbitnya Laporan Auditor Independen (LAI) (Ashton et. al., 1989).

Publik yang memiliki saham dalam perusahaan menginginkan laporan keuangan perusahaan yang diaudit segera dipublikasikan untuk mengetahui untuk mengetahui pengaruh peningkatan atau penurunan laba-rugi yang dihasilkan maupun dividen yang dibayarkan perusahaan terhadap harga saham perusahaan, adanya peningkatan laba maupun peningkatan pembayaran dividen tersebut merupakan sinyal positif dalam kenaikkan harga saham perusahaan (Khoufi \& Khoufi, 2018). Jika perusahaan tersebut telah mempublikasikan laporan keuangan dan timbul sinyal positif terhadap kenaikkan harga saham, maka shareholder akan cenderung menjual sahamnya. Oleh karena itu, ketepatwaktuan pelaporan keuangan sangat penting dalam pengambilan keputusan terkait menjual atau menahan saham yang dimiliki shareholder (WanHussin \& Bamahros, 2013). Kepemilikan saham oleh pihak publik menyebabkan adanya tekanan yang didapatkan oleh perusahaan karena semua kegiatan ekonomi perusahaan dan isu-isu terkait perusahaan akan selalu dipantau oleh publik, setiap keputusan yang dibuat manajemen akan memperoleh tanggapan dari masyarakat atau publik (Fakhfakh, 2015). Perusahaan dengan persentase kepemilikan publik yang besar, akan berusaha lebih tepat waktu dalam menyampaikan laporan keuangan yang sudah diaudit untuk menjaga kepercayaan masyarakat yang menginvestasikan dananya pada perusahaan. Oleh karena itu, perusahaan dengan persentase saham yang dimiliki oleh masyarakat atau publik lebih besar semaksimal mungkin laporan keuangan yang diaudit segera disampaikan kepada
OJK untuk menjaga kepercayaan para investor publik.

\section{Uji Pengaruh Kepemilikan Institusional Terhadap Audit Delay}

Hasil uji hipotesis penelitian ini yang ditunjukkan pada Gambar 1 membuktikan bahwa hipotesis kedua $\left(\mathrm{H}_{2}\right)$ yaitu variabel kepemilikan institusional berpengaruh positif terhadap audit delay didukung. Didukungnya hipotesis kedua $\left(\mathrm{H}_{2}\right)$ ditunjukkan dengan $p$-value sebesar $<0.01$ yang kurang dari 0.05 dan nilai beta positif $(0,26)$. Penelitian ini mendukung hasil penelitian yang dilakukan oleh Juanita \& Satwiko (2012), Kadir (2011), Fakhfakh (2015), dan Ramalingegowda \& Yu (2012) yang membuktikan bahwa temuan pada penelitian ini yaitu kepemilikan institusional berpengaruh positif terhadap audit delay. Menurut Ashton et al., (1987) pihak agen harus memiliki akuntabilitas sebagai kewajiban pemegang amanah. Hal ini menyebabkan manajemen perusahaan sebagai pihak agen berkewajiban memberikan pertanggungjawaban kinerja manajemen dengan mengungkapkan, menyajikan, dan melaporkan seluruh transakasi, aktivitas dan kegiatan bisnis yang menjadi tanggungjawab manajemen atau pihak agen kepada pihak prinsipal yaitu shareholder yang memiliki hak untuk meminta pertanggungjawaban kinerja manajemen berupa laporan keuangan tahunan. Besarnya persentase kepemilikan saham menunjukkan adanya kekuasaan dalam memegang kendali suatu perusahaan yang berimplikasi pada penentuan prosedur dan kebijakan dalam monitoring pembuatan keputusan manajemen. Shareholder yang memiliki pengaruh dalam RUPS salah satunya adalah institusional (institutional ownership).

Intitutional ownership juga memiliki hak untuk menekan manajemen perusahaan untuk menyusun laporan keuangan yang berkualitas. Intitutional ownership tidak ingin dana yang diinvestasikan pada saham perusahaan tersebut rugi (loss), karena dana yang diinvestasikan tersebut merupakan dana dari berbagai macam pihak (Bird \& Karolyi, 2016). Cornett et al., (2007) menjelaskan bahwa semakin banyak lembar saham yang dimiliki oleh perusahaan yang bergerak di bidang keuangan atau pihak institusional (intitutional ownership), maka semakin besar tekanan perusahaan untuk memiliki performance yang baik. Namun, Ramalingegowda \& Yu (2012) menyatakan bahwa intitutional ownership lebih menekankan untuk melakukan 
proses audit secara berhati-hati, karena dana yang diinvestasikan oleh intitutional ownership merupakan dana dari berbagai pihak. Hal ini menyebabkan manajemen cenderung mengingin-kan terselesaikannya pelakasanaan audit dengan berhatihati sangatlah tinggi agar intitutional ownership dapat mengembalikan dana dari berbagai pihak sekaligus mendapatkan keuntungan dari dividen dan gain dari penjualan saham. Oleh karena itu, perusahaan yang memiliki kepemilikan institusional lebih banyak memperoleh audit delay yang lebih lama.

\section{Uji Pengaruh Kepemilikan Manajerial Terhadap Audit Delay}

Hasil uji hipotesis penelitian ini yang ditunjukkan pada Gambar 1 membuktikan bahwa hipotesis ketiga $\left(\mathrm{H}_{3}\right)$ yaitu variabel kepemilikan manajerial berpengaruh negarif terhadap audit delay tidak didukung. Tidak terdukungnya hipotesis ketiga $\left(\mathrm{H}_{3}\right)$ dapat ditunjukkan dengan nilai $p$-value sebesar 0.07 yang lebih dari 0.05. Temuan dengan tidak terdukungnya hipotesis ketiga $\left(\mathrm{H}_{3}\right)$ pada penelitian ini mendukung penelitian yang dilakukan oleh Arumsari \& Handayani (2017), Butarbutar \& Hadiprajitno (2017), dan Putri \& Syahrial (2019) yang membuktikan bahwa kepemilikan manajerial tidak berpengaruh terhadap audit delay. Manajemen adalah pihak yang paling bertanggung jawab dalam menyusun pelaporan keuangan, karena manajemen yang menjalankan kegiatan bisnis secara langsung. Dewan direksi juga memiliki tanggung jawab dalam menghasilkan laporan keuangan yang berkualitas karena dewan direksi bertugas untuk menyusun laporan keuangan perusahaan yang dapat diandalkan atau tidak memihak (Mustapha \& Ahmad, 2011). Laporan keuangan dengan informasi yang andal dan akuntabel dapat menarik investor termasuk masyarakat untuk menanamkan dananya di perusahaan tersebut.

Indonesia merupakan salah satu negara yang menggunakan two-tier system. Menurut MilletReyes \& Zhao (2010) two-tier system merupakan kebijakan terkait Good Corporate Governance yang memisahkan peran dewan direksi sebagai pelaksana dan dewan komisaris sebagai pengawas. Jungmann (2007) menyatakan dengan mengguna-kan two-tier system dapat meminimalisir kecurangan, karena ada pemisahan tugas antara pelaksana dan pengawas. Manajemen sebagai pelaksana selalu diawasi oleh dewan komisaris sebagai pengawas untuk mengontrol manajemen agar tidak melakukan kecurangan. Manajemen yang memiliki saham di perusahaan dia bekerja tidak boleh menyusun pelaporan keuangan dengan informasi yang menguntungkan pihak tertentu termasuk pihak manajemen itu sendiri atau merugikan pihak lain yang mempunyai kepen-tingan berlawanan (Mustapha \& Ahmad, 2011).

Two-tier system menyebabkan manajemen yang memiliki saham perusahaan itu sendiri tidak dapat melakukan kecurangan untuk meningkatkan laba agar dividen yang dimilikinya ikut meningkat. Two tier system juga menyebabkan manajemen tidak dapat melakukan tekanan secara bebas terhadap auditor untuk mempercepat proses audit, karena komite audit yang memilih auditor dengan advice dari dewan komisaris (Dienes \& Velte, 2016). Berdasarkan Tabel 2 nilai minimum kepemilikan manajerial sebesar $0 \%$ dan nilai maksimum kepemilikan manajerial sebesar $0,9 \%$, sehingga dapat dikatakan setiap perusahaan go public memiliki kepemilikan manajerial yang persentasenya tidak signifikan. Oleh karena itu, besarnya persentase kepemilikan manajerial yang dimiliki oleh perusahaan tidak dapat mempengaruhi rentang waktu penyelesaian proses audit laporan keuangan tahunan (audit delay).

\section{Kesimpulan}

Berdasarkan Gambar 1 hasil uji hipotesis menggunakan alat statistik Warp PLS pada penelitian ini membuktikan bahwa hipotesis pertama $\left(\mathrm{H}_{1}\right)$ yaitu kepemilikan publik berpengaruh negatif terhadap audit delay didukung. Didukungnya hipotesis pertama $\left(\mathrm{H}_{1}\right)$ dapat ditunjukkan dengan nilai $p$-value sebesar <0.01 yang kurang dari 0.05 dan nilai beta negatif $(-0,25)$. Hipotesis kedua $\left(\mathrm{H}_{2}\right)$ yaitu kepemilikan institu-sional berpengaruh positif terhadap audit delay juga didukung. Didukungnya hipotesis kedua $\left(\mathrm{H}_{2}\right)$ ditunjukkan dengan p-value sebesar $<0.01$ yang kurang dari 0.05 dan nilai beta positif $(0,26)$. Namun, hipotesis ketiga $\left(\mathrm{H}_{3}\right)$ yaitu kepemilikan manajerial berpengaruh negatif terhadap audit delay tidak didukung. Tidak terdukungnya hipotesis ketiga $\left(\mathrm{H}_{3}\right)$ dapat ditunjukkan dengan nilai $p$-value sebesar 0.07 yang lebih dari 0.05 .

Penelitian ini memiliki keterbatasan, yaitu data sampel perusahaan Bank selama tahun 2016 hingga tahun 2019 tidak sesuai dengan kebutuhan peneliti yang berdampak data tidak lulus Goodness of Fit 
Test. Mayoritas perusahaan keuangan khususnya perusahaan Bank di Indonesia selalu mencatatkan audit delay kurang dari 30 hari. Srivastav \& Hagendorff (2016) menyatakan bahwa perusahaan keuangan khususnya perusahaan Bank tidak memiliki persediaan, gudang, mesin atau alat berat dan aset jangka panjang lainnya yang memerlukan cek fisik dan appraisal untuk menilai nilai wajar aset tersebut, sehingga risiko nilai wajar aset sangat kecil. Mayoritas perusahaan keuangan khususnya perusahaan Bank memiliki waktu lebih cepat dalam melaksanakan dan menyusun laporan keuangan tahunan perusahaan yang telah diaudit (audit delay) daripada perusahaan non keuangan yang memiliki persediaan, gudang, mesin atau alat berat dan aset jangka panjang lainnya (Barakat \& Hussainey, 2013). Selain itu, keterbatasan yang dimiliki pada penelitian ini yaitu adanya data perusahaan yang tidak memiliki kepemilikian manajerial, sehingga berpengaruh terhadap uji hipotesis pada penelitian ini.

Penelitian selanjutnya diharapkan dapat mengatasi keterbatasan penelitian saat ini dengan menambahkan penggunaan variabel terkait kepemilikan saham dan memperluas sampel. Hal ini digunakan agar memperoleh pandangan yang lebih objektif dan representatif yaitu dengan memasukkan lebih banyak perusahaan yang bergerak di bidang keuangan dan menambah variabel kepemilikan saham berdasarkan jenisnya. Kepemilikan saham di Indonesia tidak hanya diklasifikasikan menjadi kepemilikan publik, kepemilikan institusional, dan kepemilikan manajerial, tetapi ada kepemilikan perusahaan (company ownership) dan kepemilikan pemerintah untuk memperluas pandangan terhadap variabel kepemilikan saham (Fitza \& Tihanyi, 2017).

\section{Referensi}

Abbott, L. J., Parker, S., \& Peters, G. F. 2012. Internal Audit Assistance and External Audit Timeliness. Auditing. https://doi.org/10.2308/ajpt-10296

Arumsari, V. F., \& Handayani, N. (2017). Pengaruh Kepemilikan Saham, Profitabilitas, Leverage, Dan Opini Auditor Terhadap Audit Delay. Jurnal Ilmu Dan Riset Akuntansi.

Ashton, R. H., Willingham, J. J., \& Elliott, R. K. (1987). An Empirical Analysis of Audit Delay. Journal of Accounting Research. https://doi.org/10.2307/2491018

Barakat, A., \& Hussainey, K. (2013). Bank Governance, Regulation, Supervision, and Risk Reporting: Evidence from Operational Risk Disclosures in European Banks. International
Review of Financial Analysis. https://doi.org/10.1016/j.irfa.2013.07.002

Bedard, J. C., Johnstone, K. M., \& Smith, E. F. 2010. Audit Quality Indicators: A status Update on Possible Public Disclosures and Insights from Audit Practice. In Current Issues in Auditing. https://doi.org/10.2308/ciia.2010.4.1.C12

Bird, A., \& Karolyi, S. A. 2016. Do Institutional Investors Demand Public Disclosure? Review of Financial Studies. https://doi.org/10.1093/rfs/hhw062

Butarbutar, R. S. K., \& Hadiprajitno, P. B. 2017. Analisis FaktorFaktor yang Berpengaruh Terhadap Audit Delay ( Studi Empiris pada Perusahaan Manufaktur yang Terdaftar di Bursa Efek Indonesia Tahun 2012-2015 ). Diponegoro Journal Of Accounting, 6(3), 1-12.

Carslaw, C. A. P. N., \& Kaplan, S. E. 1991. An Examination of Audit Delay: Further Evidence from New Zealand. Accounting and Business Research. https://doi.org/10.1080/00014788.1991.9729414

Coles, J. L., Lemmon, M. L., \& Felix Meschke, J. 2012. Structural Models and Endogeneity in Corporate Finance: The Link Between Managerial Ownership and Corporate Performance. Journal of Financial Economics. https://doi.org/10.1016/j.jfineco.2011.04.002

Cornett, M. M., Marcus, A. J., Saunders, A., \& Tehranian, H. 2007. The Impact of Institutional Ownership on Corporate Operating Performance. Journal of Banking and Finance. https://doi.org/10.1016/j.jbankfin.2006.08.006

De George, E. T., Li, X., \& Shivakumar, L. 2016. A Review of The IFRS Adoption Literature. In Review of Accounting Studies. https://doi.org/10.1007/s11142-016-9363-1

Dienes, D., \& Velte, P. 2016. The Impact of Supervisory Board Composition on CSR Reporting. Evidence from The German Two-Tier System. Sustainability Switzerland. https://doi.org/10.3390/su8010063

Fakhfakh, M. 2015. Timeliness of Tunisian Audit Reports: An Empirical Investigation based on Ownership and Partnership Visions. International Journal of Financial Management. https://doi.org/10.21863/ijfm/2015.5.3.014

Fitza, M., \& Tihanyi, L. 2017. How Much Does Ownership Form Matter? Strategic Management Journal. https://doi.org/10.1002/smj.2671

Givoly, D., Hayn, C. K., \& Katz, S. P. 2010. Does Public Ownership of Equity Improve Earnings Quality? In Accounting Review. https://doi.org/10.2308/accr.2010.85.1.195

Hair, J. F., Risher, J. J., Sarstedt, M., \& Ringle, C. M. 2019. When to use and how to report the results of PLS-SEM. In European Business Review. https://doi.org/10.1108/EBR-112018-0203

Indonesia. 2011. Keputusan Ketua Bapepam Nomor Kep346/BL/2011 Tentang Penyampaian Laporan Keuangan Berkala Emiten atau Perusahaan Publik. Jakarta: Otoritas Jasa Keuangan Republik Indonesia

Ishak, I., Muhammad Sidek, A. S., \& Rashid, A. A. 2010. The Effect of Company Ownership on the Timeliness of Financial Reporting: Empirical Evidence From Malaysia. UNITAR E- 
Journal.

Jensen, M. C., \& Meckling, W. H. 1976. Theory of The Firm: Managerial Behavior, Agency Costs and Ownership Structure. Journal of Financial Economics. https://doi.org/10.1016/0304405X(76)90026-X

Juanita, G., \& Satwiko, R. 2012. Pengaruh Ukuran Kantor Akuntan Publik, Kepemilikan, Laba Rugi, Profitabilitas dan Solvabilitas Terhadap Audit Report Lag. Jurnal Bisnis Dan Akuntansi, 14(1), 31-40.

Jungmann, C. 2007. The Effectiveness of Corporate Governance in One-Tier and Two-Tier Board Systems: Evidence from the UK and Germany. European Company and Financial Law Review. https://doi.org/10.1515/ecfr.2006.019

Kadir, A. 2011. Faktor-Faktor Yang Berpengaruh Terhadap Ketepatan Waktu Pelaporan Keuangan: Studi Empiris Di Bursa Efek Jakarta. Jurnal Manajemen Dan Akuntansi, 12(April), 1-12.

Khoufi, N., \& Khoufi, W. (2018). An Empirical Examination of The Determinants of Audit Report Delay in France. Managerial Auditing Journal. https://doi.org/10.1108/MAJ-02-2017-1518

Lafond, R., \& Roychowdhury, S. (2008). Managerial ownership and accounting conservatism. Journal of Accounting Research. https://doi.org/10.1111/j.1475-679X.2008.00268.x

Metta, C., \& Effriyanti, E. (2020). Pengaruh Ukuran Perusahaan, Kepemilikan Publik Dan Penerapan International Financial Reporting Standards (IFRS) Terhadap Audit Report Lag. Jurnal Ilmiah Akuntansi Universitas ..., 8(1), 1-14.

Millet-Reyes, B., \& Zhao, R. (2010). A comparison between onetier and two-tier board structures in France. Journal of International Financial Management and Accounting. https://doi.org/10.1111/j.1467-646X.2010.01042.x

Mustapha, M., \& Ahmad, A. C. (2011). Agency theory and managerial ownership: Evidence from Malaysia. Managerial Auditing Journal. https://doi.org/10.1108/02686901111129571
Napisah, L. S., \& Ramadhani, V. (2020). Pengaruh Ukuran Perusahaan, Laba/Rugi Operasi, dan Kepemilikan Publik Terhadap Audit Delay Studi PadaPerusahaan Manufaktur yang Terdaftar di BEI Tahun 2016 - 2018. Jurnal Riset Akuntansi Dan Bisnis Jurnal Riset Akuntansi Dan Bisnis, 6(2), 109-117.

Panda, B., \& Leepsa, N. M. 2017. Agency Theory: Review of Theory and Evidence on Problems and Perspectives. Indian Journal of Corporate Governance. https://doi.org/10.1177/0974686217701467

Payne, J. L., \& Jensen, K. L. 2002. An Examination of Municipal Audit Delay. Journal of Accounting and Public Policy. https://doi.org/10.1016/S0278-4254(02)00035-2

Putri, G. A., \& Syahrial, Y. 2019. Kontribusi Good Corporate Governance Untuk Mengurangi Terjadinya Audit Delay. Jurnal Penelitan Ekonomi Dan Bisnis, 4(2), 78-88. https://doi.org/10.33633/jpeb.v4i2.2401

Ramalingegowda, S., \& Yu, Y. 2012. Institutional Ownership and Conservatism. Journal of Accounting and Economics. https://doi.org/10.1016/j.jacceco.2011.06.004

Srivastav, A., \& Hagendorff, J. 2016. Corporate Governance and Bank Risk-taking. Corporate Governance: An International Review. https://doi.org/10.1111/corg.12133

Suryanto, T. 2016. Audit Delay and Its Implication for Fraudulent Financial Reporting: A Study of Companies Listed in The Indonesian Stock Exchange. European Research Studies Journal. https://doi.org/10.35808/ersj/503

Wan-Hussin, W. N., \& Bamahros, H. M. 2013. Do Investment in and The Sourcing Arrangement of The Internal Audit Function Affect Audit Delay? Journal of Contemporary Accounting and Economics. https://doi.org/10.1016/j.jcae.2012.08.001

Zogning, F. 2017. Agency Theory: A Critical Review. European Journal of Business and Management. 